\title{
JURISDICTION IN INSURANCE MATTERS AND THE “WEAKER PARTY”
}

IN Aspen Underwriting Ltd v Credit Europe Bank NV [2020] UKSC 11, [2020] 2 W.L.R. 919, the Supreme Court had a rare opportunity to consider the insurance provisions of the Brussels I Regulation Recast (“BIR”). The Court's comments will be of significant interest to conflicts, insurance and EU lawyers, as well as those dealing with other provisions of the BIR designed to protect the weaker party, namely the consumer and employment provisions.

The facts concerned a large and audacious attempted insurance fraud. Aspen Underwriting Limited ("the Insurer") was the insurer of a vessel called the Atlantik Confidence. Credit Europe Bank NV ("the Bank") was a mortgagee of the vessel and assignee of the insurance policy, which contained an exclusive English jurisdiction clause. The Atlantik Confidence sank in the Gulf of Aden. The Insurer entered into a settlement agreement with the owners and managers of the vessel and paid the brokers (at the Bank's direction) under the policy. The Admiralty Court subsequently held that the owner's alter ego had procured scuttling of the vessel: [2016] EWHC 2412, [2016] 2 Lloyd's Rep 525. The Insurer commenced proceedings against the owners, managers and the Bank to recover sums paid under the settlement agreement. The Bank, domiciled in the Netherlands, challenged the English Court's jurisdiction.

Three main issues were addressed in the sole judgment given by Lord Hodge. The first question was whether the Bank was bound by the jurisdiction clause in the insurance policy, such that the English Court had jurisdiction under Articles 15 or 25 BIR. The second issue was whether the Insurer's claims fell within "matters relating to insurance" in Section 3 BIR. The significance of this was that Article 14(1) BIR provides that "an insurer may bring proceedings only in the courts of the Member State in which the defendant is domiciled, irrespective of whether he is the policyholder, the insured or a beneficiary" (which would have been the Dutch Courts). If so, the third issue was whether the Bank was nevertheless prevented from relying on the provisions of Article 14 because it was not a weaker party than the insurer.

The Court answered the first question in the negative. The Bank had not become a 'successor' to rights and obligations contained within the policy, as required by The Tilly Russ (Case 71/83) [1985] Q.B. 931 (at [24]-[26]). In particular, pursuant to English law the Bank had become only an equitable assignee of the policy (at [26]). Such an assignee could in principle be bound by conditions or qualifications on the exercise of contractual rights, 
including jurisdiction provisions, by virtue of the 'conditional benefit' principle described by Hobhouse L.J. in The Jay Bola [1997] 2 Lloyd's Rep 279 (which Lord Hodge referred to as "the best encapsulation" of the principle: at [27]). That principle, however, operated only to prevent claims being asserted inconsistently with the relevant conditions or qualifications. In this case the Bank had neither commenced legal proceedings nor asserted any claim and there was therefore no inconsistency (at [29]).

As to the second issue the Supreme Court held that the Insurer's claims were "matters relating to insurance" (at [41]), rejecting a submission that Section 3 BIR applies only where the claim is, at least in substance, for breach of an obligation in an insurance contract. That was primarily because, unlike Sections 4 and 5 (relating to "consumer contracts" and "individual contracts of employment" respectively), the heading of Section 3 does not refer to insurance contracts (at [35]). In addition, Section 3 governs the rights of "beneficiar[ies]" and "injured part[ies]" who would not generally be parties to any contract(s) of insurance (at [36]). The BIR's Recitals did not support any conclusion to the contrary (at [37]).

The Court's decision on the third issue is likely to have the greatest significance, but is also the most difficult. The Court concluded that " $\mathrm{t}]$ here is no 'weaker party' exception which removes a policyholder, an insured or a beneficiary from the protection of Article 14" (at [43]). Lord Hodge gave six reasons for his conclusion that the position was acte clair (at [43]), including that "derogations from the jurisdictional rules in matters of insurance must be interpreted strictly".

It is doubtful that this interpretation of the CJEU case law was acte clair. The problem with the Supreme Court's conclusion that the point was acte clair, as well as its position on the substantive issue, is well demonstrated by the decision in Case C-347/08 Vorarlberger Gebietskrankenkasse v WGV-Schwäbische Allgemeine Versicherungs AG [2009] E.C.R. I8661. Vorarlberger concerned Article 11(2) BIR, which concerned "direct actions" by an “injured party” against an insurer. Article 11(2) applied inter alia Article 9(1)(b) of Brussels I, which allowed a Claimant "policyholder ... insured or ... beneficiary" to bring an action against an insurer in the Claimant's country of domicile. The CJEU held that a statutory assignee of the victim could benefit from those provisions if the assignee were an heir of the victim (at [44]) but not (as on the facts of Vorarlberger itself) if the assignee were a social security institution (at [43]). That was because an heir "may ... be considered to be a weaker party" (at [44]), whilst a social security body could not. A weaker party requirement accordingly applies to at least some definitional terms in the BIR's insurance provisions, including the term “injured party”. Although Case C-463/06 FBTO Schadeverzekeringen NV v Odenbreit [2008] 
2 All E.R. (Comm) 733 held that a victim could bring a "direct action" against an insurer without necessarily qualifying as a "beneficiary" (or the other categories listed in Article $9(1)(b))$ (at [27]), it is difficult to see how there could have been "no scope for any reasonable doubt" (Case 283/81 CILFIT Srl v Ministro della Sanita [1983] 1 C.M.L.R. 472, at [21]) whether the Vorarlberger approach also applies to the term "beneficiary" in Article 14(1) BIR.

Lord Hodge was correct to say that the CJEU has "set its face against a case by case analysis of the relative strength or weakness of contracting parties" (at [43]), but it does not follow that no such weaker party requirement applies. The requirement demands instead that the relevant party's strength be determined as a class of persons, rather than according to the party's individual circumstances: Case C-340/16 Landeskrankenanstalten-Betriebsgesellschaft - KABEG v Mutuelles du Mans assurances - MMA IARD SA [2017] I.L. Pr. 31 (at [34]-[35]), and Y. Baatz, "Matters relating to insurance and protecting the weaker party" (2018) L.M.C.L.Q 1, at 4, 6 .

As to the Supreme Court's approach to construction, it is a well-established principle that derogations from the general rule that a defendant should be sued in its country of domicile (contained within Article 4 BIR) ought to be strictly construed. In determining the second and third issues set out above, however, the Supreme Court considered that the insurance rules in Article 14 BIR did not derogate from that general rule. On the contrary, the Court considered that they supported the general rule because Article 14 "requires the insurer to bring proceedings only in the courts of the ... domicile of the insured" (at [57]).

This is not consistent with the CJEU's approach to construction of the relevant provisions. In Vorarlberger the Court stated that Article 3(1) Brussels I (now Article 5(1) BIR), which applied inter alia the predecessor to Article 14 BIR (i.e. Article 12 Brussels I), "derogate[ed] from the general principle" (at [37]-[38]). The effect of the 'no derogation' principle in the context of the insurance provisions is that they "should not be extended to persons for whom that protection is not justified" (at [41]). In other words, Article 14 ought not to be extended to persons other than those who are - as a class - economically weaker and less experienced in legal matters: Case C-412/98 Universal General Insurance Co v Group Josi Reinsurance Co SA [2001] Q.B. 68 (at [65]).

Finally, the Supreme Court's decision opens a gulf between the insurance provisions and the consumer contract provisions in Section 4 BIR, the purpose of which is similarly to "protect the consumer as the party ... deemed to be economically weaker and legally less experienced": Case C-89/91 Shearson Lehman Hutton Inc v TVB Treithandgesellschaft für Vermögensverwaltung und Beteiligungen mbH [1993] I.L. Pr. 199 (at [18]). In Shearson 
Lehman, a corporate entity to whom an individual's claim had been assigned was held not to be entitled to benefit from the consumer contract provisions in the Brussels Convention on jurisdiction and the enforcement of judgments in civil and commercial matters 1968 (at [24]). There is accordingly in effect a weaker party requirement in relation to consumer contracts. On the Supreme Court's approach, the same does not appear to be true for matters relating to insurance.

JOSHUA FOLKARD*

* Address for correspondence: 4 New Square, Lincoln's Inn, London, WC2A 3RJ. Email: j.folkard@4newsquare.com. 